\title{
Recent drumlins, flutes and lineations at Vestari-Hagafellsjökull, Iceland
}

\author{
JANE K. HART \\ Department of Geography, University of Southampton, Southampton SO9 5NH, England
}

\begin{abstract}
In the foreland of the Vestari-Hagafellsjökull glacier, Langajökull, central Iceland, three scales of subglacial bed forms are found: drumlins, flutes and lineations. The smaller bed forms are superimposed upon the larger. These three bed forms probably formed as a result of the presence of a rigid subglacial core producing a lee-side low-pressure area into which sediment flowed and collected. The cores of the drumlins are tumuli (lava blisters), whilst the cores of the flutes and lineations were large clasts.

Differences between the three scales of bed forms are that: (a) the flutes and lineations are far more mobile features as their cores could move within the deforming layer, whilst the drumlin bedrock cores were fixed; (b) the lineations formed in association with a clast pavement.

The change in scale of the bed forms may be related to changes in thickness of the deforming layer and size of the core. At this site, smaller bed forms were superimposed upon larger bed forms and these may have formed as the deforming layer progressively thinned in association with glacial retreat.
\end{abstract}

\section{INTRODUCTION}

A diversity of streamlined drift features is found in the glacier foreland of Vestari-Hagafellsjökull, an outlet glacier of the Langajökull ice cap, central Iceland (Fig. 1). These include: drumlins defined as large $(>0.5 \mathrm{~m}$ high) elliptical bed forms, flutes as small $(>0.2 \mathrm{~m}$ high $)$ elongated bed forms and lineations as very small $(<0.2 \mathrm{~m}$ high) very elongated features (often only one clast high). Vestari-Hagafellsjökull is a relatively clean glacier with a low surface slope moving over outwash sand and very fine-grained till. This unconsolidated mixture is watersaturated at the glacier margin. Beneath the unconsolidated sediments there are tumuli (lava blisters) of pahoehoe lava.

The southern Langajökull area is less well studied relative to other Icelandic ice caps, such as Vatnajökull, because of problems of accessibility and fresh-water shortage. The proglacial drift features have not been dated. Lichens are rare and there is no accurate lichen curve. However, there are four sets of air photographs of this area, taken in 1945, 1960, 1979 and 1991, as well as a 1937-38 topographic map. Additionally, there are data on marginal positions at three times (Sigurdsson, 1988).

Details of the area, the three known ice limits and one other older limit of unknown age, are shown in a geomorphological map (Fig. 2). The furthermost limit is assumed to represent the Little Ice Age maximum, which was thought to have occurred around 1890 in Iceland (Thórarinsson, 1943). Since then the glacier retreated steadily from the early 1900s until 1961. Sigurdsson (1988) has recorded that between 1934 and 1961 the retreat was $1306 \mathrm{~m}$. Between 1961 and the mid-1980s it re-advanced $249 \mathrm{~m}$. In 1979, it surged $700 \mathrm{~m}$ (Theódórsson, 1980) but since 1986 it has retreated again.

The till in this area is very sandy as it is a mixture of ash and outwash sand. There were so few clasts within the matrix that till-fabric analysis was possible only during the study of the lineations, which occur associated with a clast pavement.

This paper discusses the geomorphology of the glacial foreland, followed by the presentation of a model for the subglacial streamlined bed-form development at a range of scales.

\section{THE DIFFERENT GEOMORPHOLOGICAL AREAS}

The glacier foreland of Vestari-Hagafellsjökull consists of four geomorphological zones that lie parallel to the glacier margin (Fig. 2) These are discussed in turn below.

\section{Tumuli zone}

The outermost zone consists of tumuli of pahoehoe lava (Fig. 3a). Tumuli are formed either by pressure from stillliquid lava flowing beneath the solidifying surface, or pressure associated with volatilization of ground water (Cas and Wright, 1986). These tumuli are 1-2 m high and they show no evidence of having been glaciated.

\section{Lake bed zone}

Closer to the glacier, there is large flat clay plain that was formerly covered by water. This lake, Sandvatn, is shown on the 1937-38 topographical map and 1945 air 

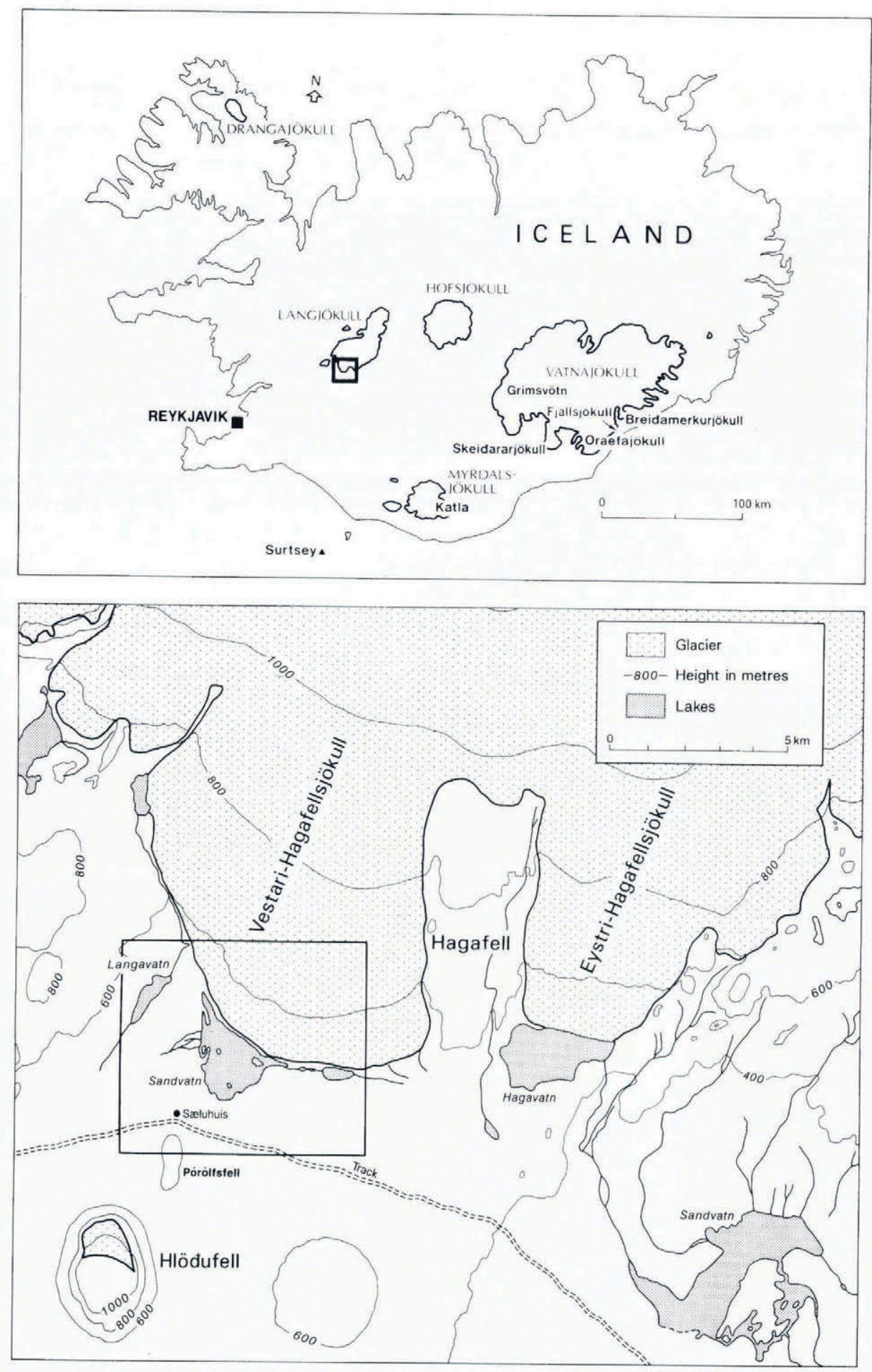

Fig. 1. Location of the site. Map based on the 1937-38 topographic map.

photographs but by 1960 it had drained. The southernmost limit of the lake is approximately coincident with the maximum ice extent. Within the lake bed are morainic features up to $5 \mathrm{~m}$ high, some of which have steep icecontact slopes. These probably represent end moraines and erosional remnants of a sandur deposit developed during retreat between 1890 and 1945 .

\section{Outer drumlin zone}

The outer drumlin zone consists of drumlinized tumuli (Figs $3 \mathrm{~b}$ and 4 ). These have a classical drumlin shape and a rock core although they are only $1-2 \mathrm{~m}$ high, 20-30 m long and 10-20 $\mathrm{m}$ wide. The upper surfaces of the rock cores are commonly striated in the direction of ice flow. Since drumlins are formed subglacially, they were exposed between 1890 and 1960. The till in this zone has a complete moss cover and consists of sand and ash with only a few clasts.

A series of end moraines, formed as the glacier retreated, traverses this zone. These moraines are probably push moraines which are common in Iceland e.g. Fjallsjökull, Breiðamerkurjökull and Skalafellsjökull in southeast Iceland (Price, 1970; Sharp, 1984; Boulton, 1986). They are probably formed by longitudinal compression by the glacier, squeezing out due to the 


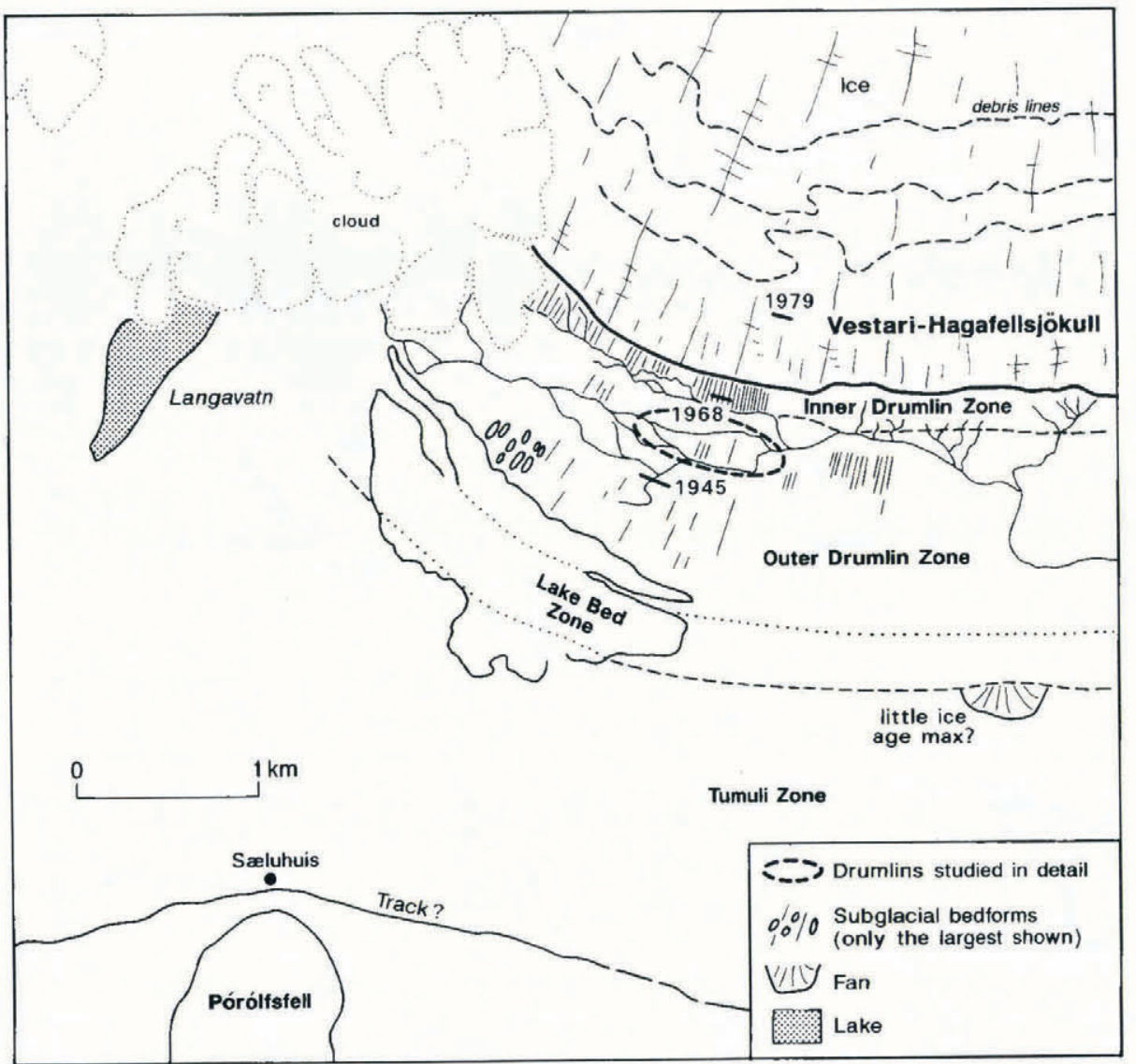

a

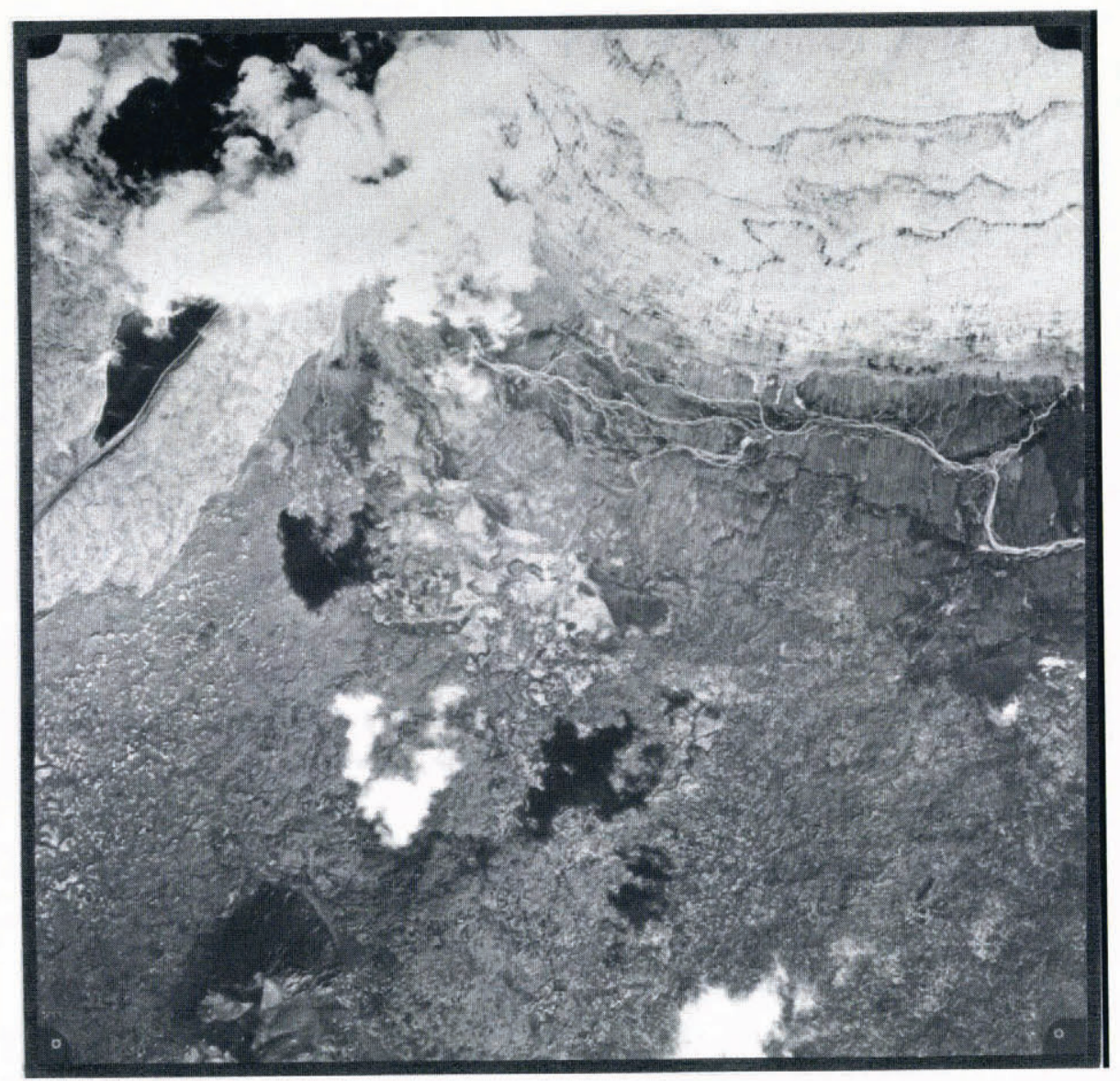

b

Fig. 2. (a) Air photograph of the area in 1991. (Reproduced with permission from Landmelingar Islands.) (b) Geomorphological map of the area. Short heavy lines with dates 1945, 1968 and 1979 are ice-marginal positions taken from air photographs. 


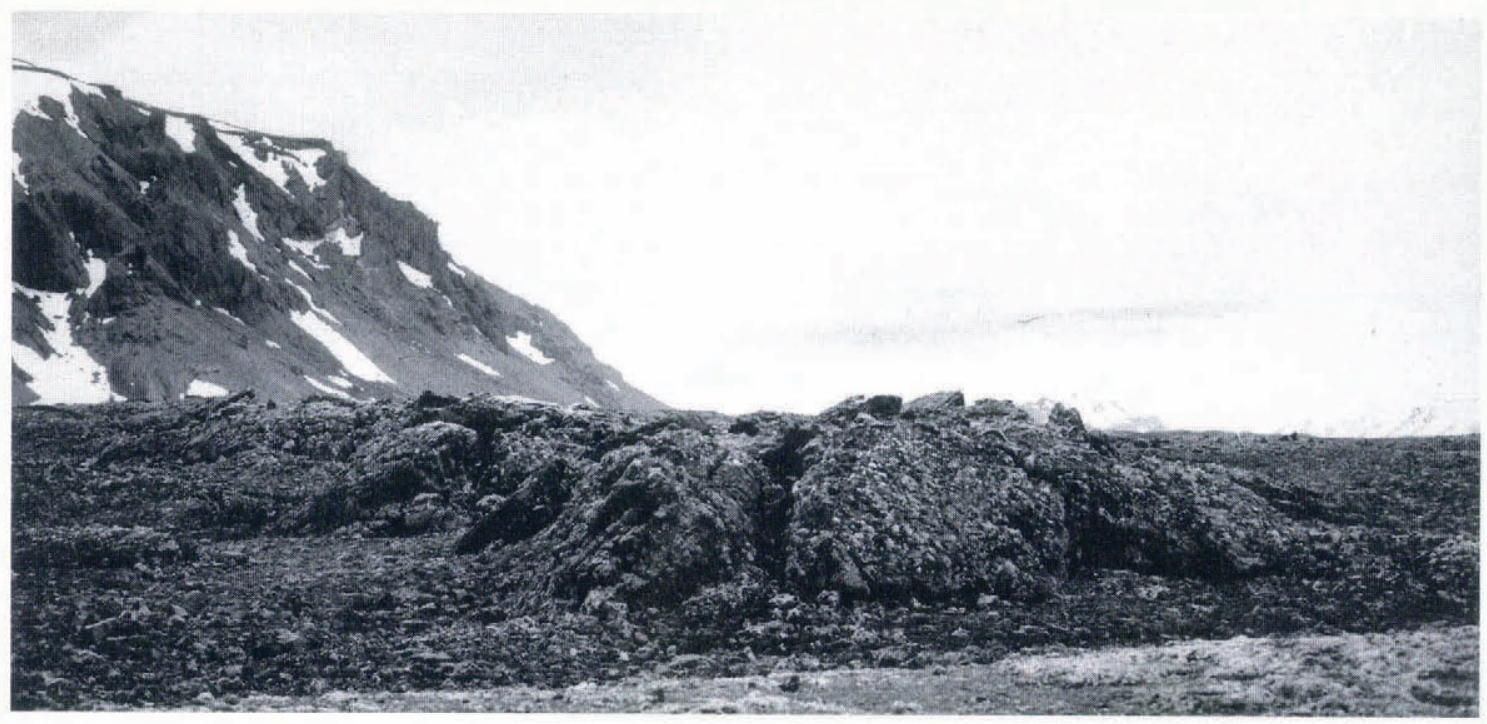

$\mathbf{a}$

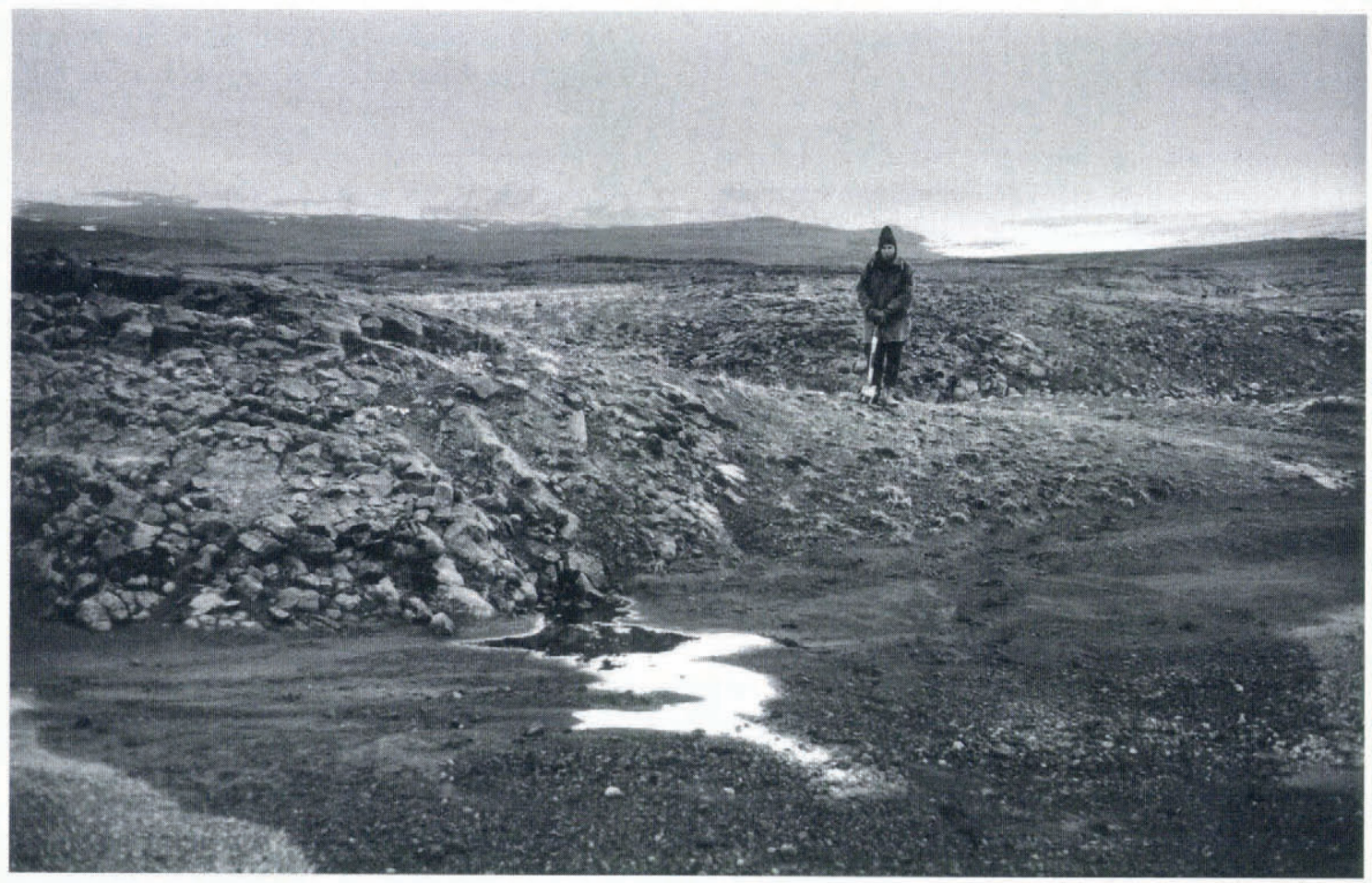

b

Figg. 3. (a) Pholograph of a tumulus. (b) Photograph of a drumlinized tumulus. Ice-flow direction was from left to right.

weight of ice and also by the down-glacier movement of sediment (advection) within the deforming layer (Hart, 1990).

In order to study their composition, the drumlins in a small area (Fig. 2) were examined and a number of excavations were made. Some drumlins were examined in more detail and the results are shown in Figure 4. The drumlins were divided into four classes and the number in each class was recorded (Table 1). The four classes were defined as: (a) rock drumlin - a tumulus which is composed of rock but shows evidence of glacial striae and streamlining; (b) till drumlin-drumlins that

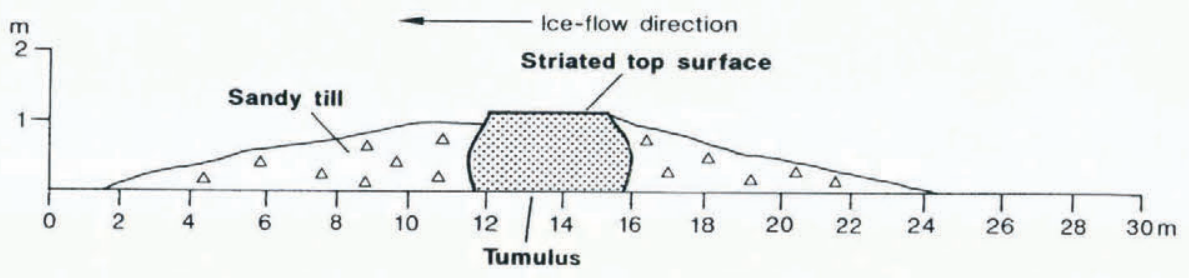

Fig. 4. Cross-section of a drumlin in the outer drumlin zone. 
Table 1. Different types of drumlins

\begin{tabular}{lrrrl}
\hline Drumlin type & No. & $\%$ & $\begin{array}{c}\text { Average } \\
\text { height } \\
\mathrm{m}\end{array}$ & S.D. \\
& & & & \\
\hline Rock drumlin & 6 & 15 & 0.7 & 0.4 \\
Till drumlin & 3 & 8 & 0.53 & 0.05 \\
Rock-cored drumlin & 18 & 46 & 1.5 & 0.78 \\
Rock cored with tail & 12 & 31 & 1.08 & 0.5 \\
\hline
\end{tabular}

excavations suggested were probably composed entirely of till; (c) rock-cored drumlin - a tumulus core with a till carapace (shown in Figure 4); (d) rock core with a trail. The majority of the drumlins were rock-cored $(46 \%)$ or had a rock core with a tail $(31 \%)$. Only a small number were composed entirely of either rock or till.

\section{Inner drumlin zone}

The inner drumlin zone is far more complex. Ice readvanced over this area between 1961 and the mid-1980s as noted and thus the ground surface is unvegetated. The zone's southern end is marked by a $2 \mathrm{~m}$ high end moraine, which is probably a push moraine. The rest of the area is covered by small drumlins, similar in dimensions to those in the outer drumlin zone. However, many of these drumlins have flutes superimposed on their surfaces. The flutes consist of a boulder on the up-glacier end with a long lee-side accumulation of till (Fig. 5).

Close to the ice margin there are many flutes and also a series of lineated surfaces. The lineated surfaces consist of lines of clasts, $0.02-0.05 \mathrm{~m}$ wide, that are oriented in the same direction as the flutes and drumlins, and spaced approximately $0.1 \mathrm{~m}$ apart. They usually contain no matrix but consist entirely of clasts, which sometimes coarsen upwards. Beneath them there is a fine sandy till which has very few clasts. Similar lineations are also superimposed on the drumlins. There are four different types of lineation:

(a) The first group (type a) consists of a large clast (approximately $0.5 \mathrm{~m}$ long) which has a lee-side till prow and a stoss-side tail of clasts (Fig. 6a). The prow in Figure 6a consists of a $0.05 \mathrm{~m}$ thick dome of till pushed up by the large clast. A till-fabric analysis of the clasts in the tail produced $\mathrm{S} 1$ and $\mathrm{S} 3$ values of 0.660 and 0.028 , respectively, ${ }^{*}$ orientated parallel with the lineation.

(b) The second group (type b) shows a similar pattern but with a longer lee-side prow forming a till ridge that often coalesces with those from other clasts. Only the largest clasts have a stoss-side clast tail (Fig. 6b).

\footnotetext{
* These eigenvalues (S1, S2 and S3) summarize fabric strength along the three principal directions of clustering (after Mark (1973) and Dowdeswell and Sharp (1986)). A fabric with no preferred orientation (weak fabric) would have equal eigenvalues, whilst a strong fabric would have a high value in the direction of maximum clustering $(\mathrm{S} 1)$, which is usually the direction of tectonic transport, and a low value in the direction of least clustering (S3). All till-fabric data discussed in this paper relate to sites where a minimum of 25 clasts with an axial ratio greater than $1.5: 1$ were sampled.
}

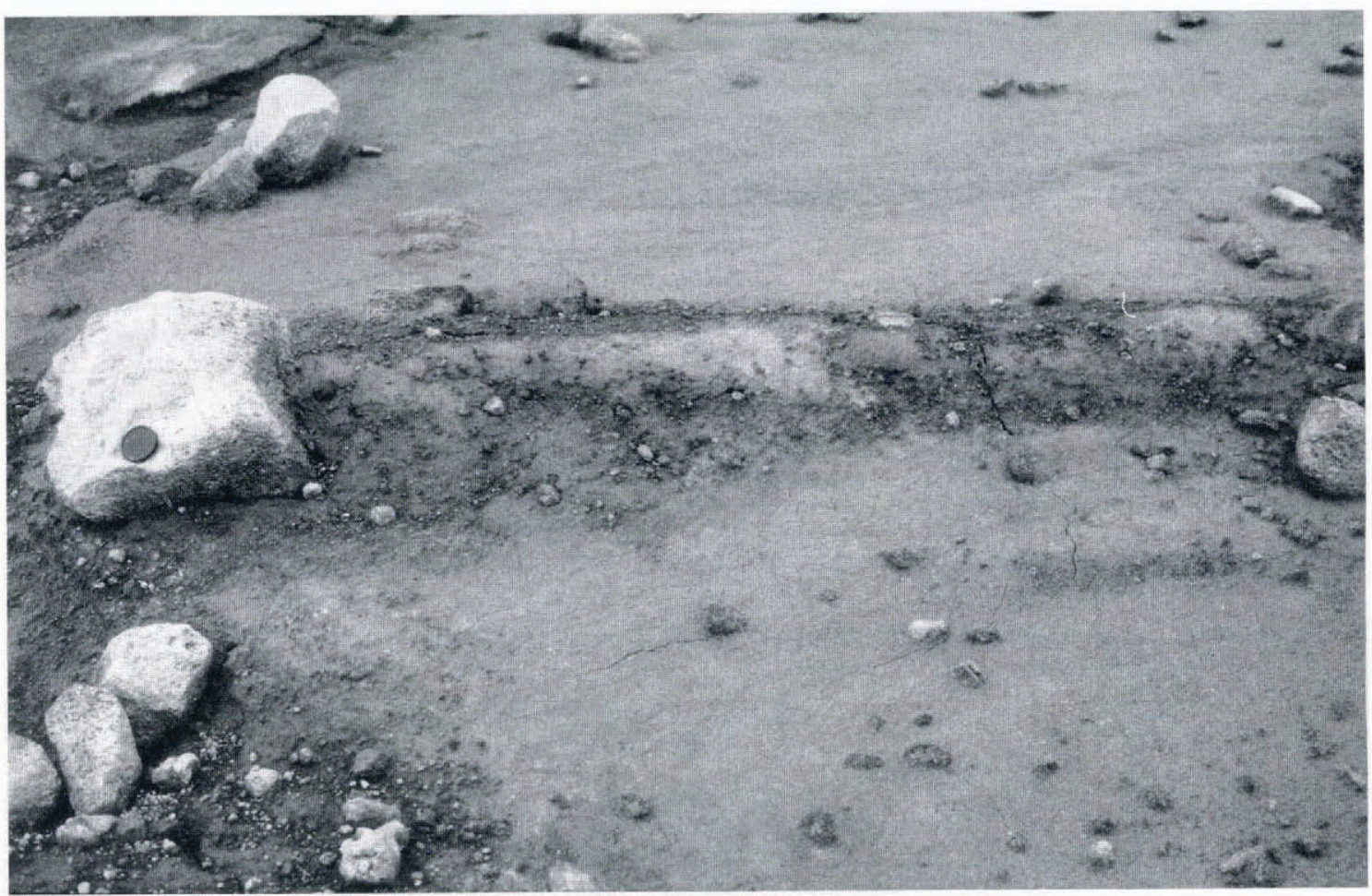

Fig. 5. Photograph of a flute in the inner drumlin zone. Approximate dimensions of the large clast: $0.3 \mathrm{~m}$ by $0.25 \mathrm{~m}$ by $0.1 \mathrm{~m}$. 

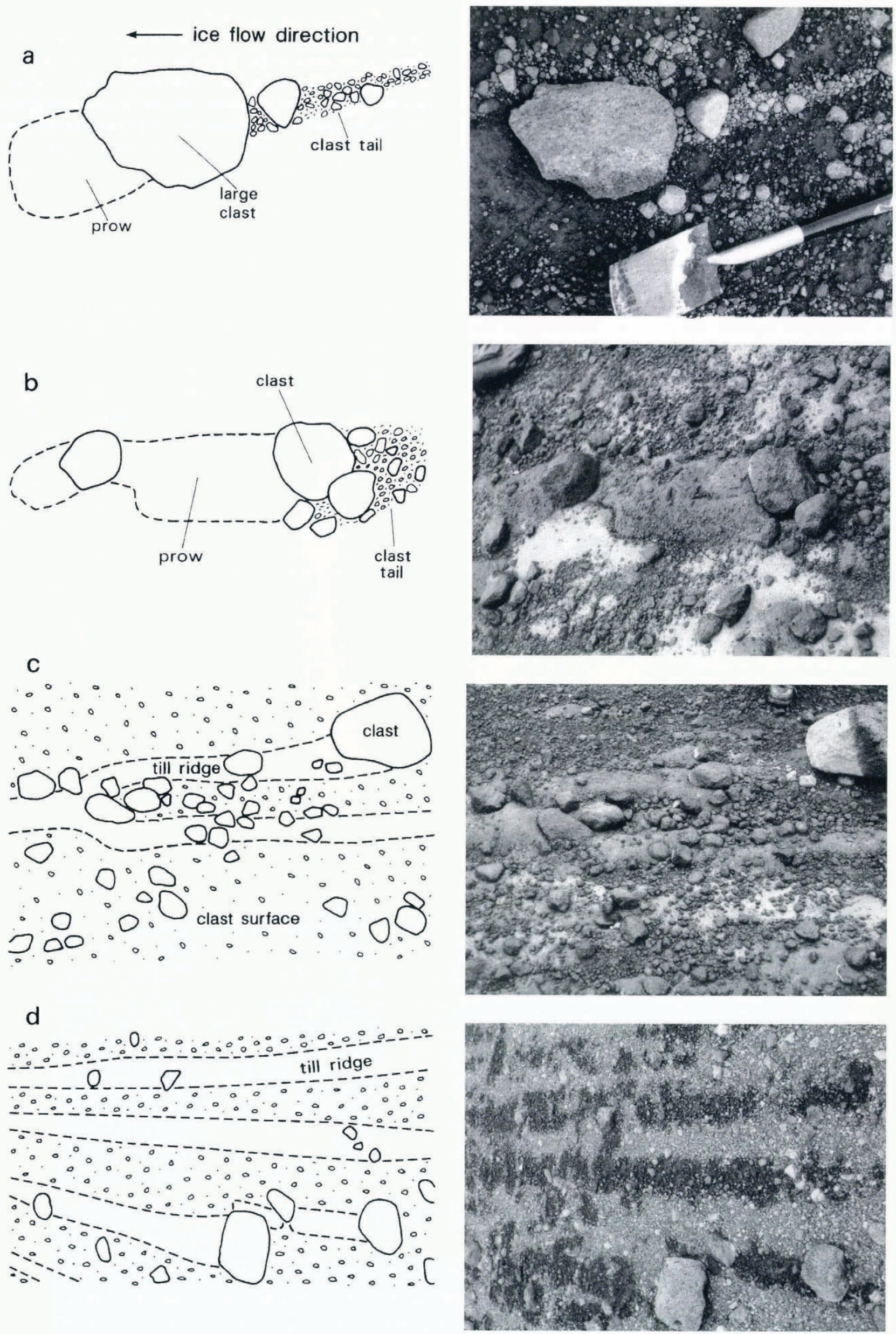

Fig. 6. Photographs and interpretative sketch maps of the four types of linealed surface in the inner drumlin zone. 
These larger clasts are, however, only $0.2 \mathrm{~m}$ wide and are oriented transverse to ice flow.

(c) The third group (type c) is slightly more complex. In these, relatively clast-free till is raised in ridges above surfaces with abundant clasts. The till ridges appear to emanate from large clasts most are approximately $0.2 \mathrm{~m}$ long) that are orientated in the direction of ice flow (Fig. 6c). The till ridges also coalesce and at some of the junctions there is a large clast that appears to have been ploughed into the till. A till-fabric analysis of the clasts in the central clastrich furrow (shown in Figure 6c) produced S1 and S3 values of 0.825 and 0.008 , respectively.

(d) The fourth group (type d) consists of alternating lines of high and low clast content. Zones of lower clast content are topographically higher. These zones appear in the lee of large clasts but these large clasts are not ploughed into the surface and many are oriented transverse to ice flow (Fig. 6d). The largest clast is about $0.4 \mathrm{~m}$ across. A till-fabric analysis of the clasts in the clast-rich areas produced $\mathrm{S} 1$ and $\mathrm{S} 3$ values of $0.548,0.002$, respectively.

At the margin, there is a $10 \mathrm{~m}$ wide zone of watersaturated subglacial material (Fig. 7). Here, the on-going glacier retreat is exposing composite drumlins up to $3 \mathrm{~m}$ high. One particular feature, $2 \mathrm{~m}$ high, has a tumulus core which is highly plucked on its lee face, indicating that it was a roche moutonnée before the drumlinizing event. The main body of the feature is in the shape of the drumlin but it has a very long (over $100 \mathrm{~m}$ ) tail (flute) down-glacier from it. The tail is composed both of the very sandy till and of angular blocks which have probably been plucked from the tumulus.

\section{DISGUSSION}

Vestari-Hagafellsjökull represents a glacier under which there is a very high probability that the subglacial sediment is deforming. The evidence for this is that the glacier surface has a low slope, the glacier is moving over a potentially weak unconsolidated sandy ash-rich till and at the margin the till is highly saturated. These conditions are those that Boulton (1979), Alley and others (1986) and Boulton and Hindmarsh (1987) suggested are conducive to deformation of the bed. Several of the explanations, given below, for the origin of the observed streamlined features require a deforming bed and, conversely, they would be difficult to explain if the bed were not deforming.

At Vestari-Hagafellsjökull, there are three scales of streamlined bed forms being exposed on the glacier foreland: drumlins, flutes and lineated surfaces. Studies of flutes associated with contemporary glaciers are common (e.g. Blomstrandbreen, Spitsbergen - Paul and Evans, 1974; Breiðamerkurjökull, Iceland - Boulton, 1976; Isfallsglaciären, Sweden - Amark, 1980; Austre Okstindbre, Norway - Rose, 1989; Lyngsdalen, Norway-Gordon and others, 1992) but studies of recently exposed drumlins are less common (e.g. Krüger and Thomsen, 1984). Rose (1987) suggested that there is a continuum of streamlined land forms from small highly elongated flutes to larger less elongated drumlins, formed by similar processes. At Vestari-Hagafellsjökull, there is an opportunity to test this model as there was such a range in scale of subglacial streamlined bed forms. Rose (1987) divided up the streamlined bed forms on the basis of scale, as I have in this paper.

\section{The Vestari-Hagafellsjökull flutes}

Flutes tend to consist of a stoss-side clast, which acts as a

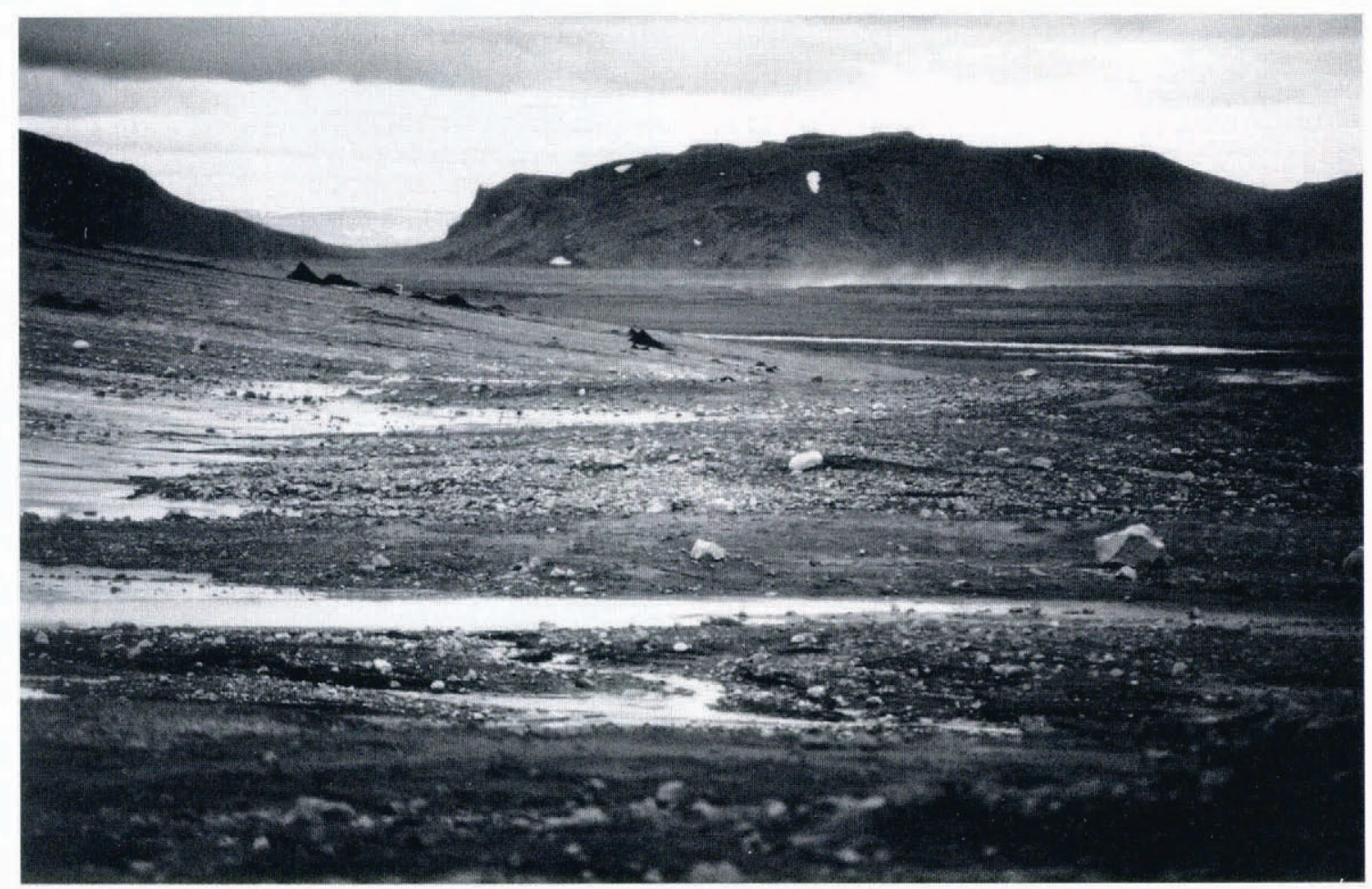

Fig. 7. Photograph of the ice margin. 
core, with a long lee-side till tail (Dyson, 1952; Boulton, 1976; Rose, 1989; Benn, 1994). Most modern authors have suggested that flutes form as a large clast is dragged through the subglacial sediment until it becomes lodged, whereupon saturated till flows into the low-pressure zone or cavity in the lee of the clast. Thus, flutes may be indicative of deforming bed conditions.

The pattern of till movement within the deforming layer has been well demonstrated by till-fabric studies by the authors mentioned above. Additionally, Rose (1989) showed that the flow then diverges at the down-glacier end of the flute (Fig. 8). Although Rose (1989) suggested that this represents ice flow, it seems more likely that it represents sediment flow within the deforming layer as suggested by Boulton (1976) and Benn (1994). Gordon and others (1992) have suggested other processes of flute formation but they failed to produce substantial evidence to disprove the more widely accepted model outlined above. Similarly, Dreimanis (1993) has suggested that flutes with crescentic scours at their proximal ends may have a subglacial fluvial origin. However, this type of proximal erosion was not observed at Vestari-Hagafellsjökull.

The flutes at Vestari-Hagafellsjökull show characteristics similar to those of the flutes discussed above and so it is most likely that they too were formed by movement of saturated till into the lee of a larger clast.

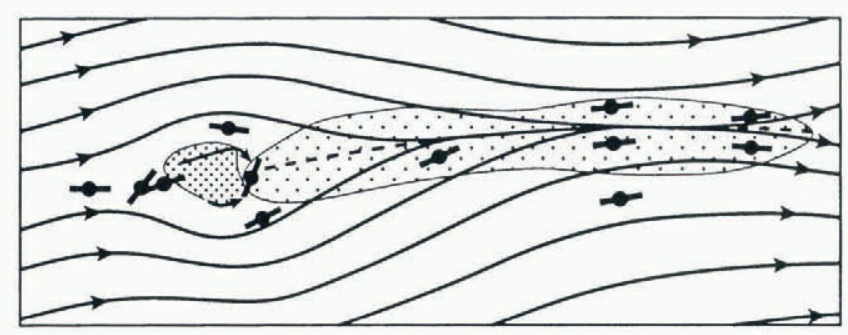

Fig. 8. Flow of sediment in flute (after Rose, 1989). Closely spaced dots represent initiating rock. Widely spaced dots are the flute. Dots with bars show the sile of tillfabric analysis. Lines with arrows show inferred direction of flow based on till fabrics.

\section{The Vestari-Hagafellsjökull drumlins}

Although there have been many models proposed for drumlin formation (see Menzies, 1984), at the moment most researchers support one of two theories. In the first, based on the ideas of Smalley and Unwin (1968) and elaborated upon by Menzies (1979) and Boulton (1987), it is suggested that drumlins form when material flows around more competent obstructions within the subglacial deforming layer. The core can be composed either of a clast of hard rock or a more competent mass of soft sediment, such as sand and gravel or till. The other theory, proposed by Shaw (1983) suggests that drumlins form either as depositional bed forms from subglacial fluvial scour of the ice base or are erosional features from large catastrophic subglacial discharges.

The latter theory has little relevance to the present study, as the drumlins at Vestari-Hagafellsjökull were not formed of sand and gravel and there was no evidence of unusually large subglacial discharges. Instead, the drumlins at Vestari-Hagafellsjökull were composed of a tumulus core with a lee side (and sometimes a stoss side) accumulation of till. Thus, the drumlins appear to be a larger-scale example of the flutes and I suggest that they may well have been formed in a similar manner. That is, subglacial saturated till moved into the low-pressure area in the lee of the tumulus cores. If this is true, then these are a type of deforming bed drumlin.

\section{The Vestari-Hagafellsjökull lineations}

It has been shown above that there were four different, but related, types of lineation. These lineations consist of a clast-rich layer, of single-clast thickness, resting on a sandy, almost clast-free till. Krüger (1993) described a similar clast-paved till from Myrdalsjökull, Iceland. Krüger and Humlum (1981) described these clasts as being in traction against the glacier bed. However, Krüger (1993) noted that only $43 \%$ of the clasts in the upper clast unit were striated, although most striations were on the lower surface.

Based on the frictional lodgement theory of Boulton (1975), Krüger (1993) interpreted the clast-rich layer and the underlying till to be lodgement till because of grainsize composition, clast shape and roundness, striations, till fabric and small-scale deformation structures. However, subsequent work has shown that many of these parameters, particularly the latter, are indicative of subglacial deformation (e.g. Hart and Boulton, 1991; Hicock and Dreimanis, 1992) and strong till fabrics can be indicative of either lodgement till or deforming bed till associated with a thin deforming layer (Hart, 1994).

This problem of the origin of the clast-rich surface will be discussed later. However, given its existence, the various types of lineation are interpreted as follows.

The type a lineations consist of a large clast with a leeside prow and a stoss-side tail. The large clast seems to have ploughed into the sediment as described theoretically by Brown and others (1987) and from field evidence by Clark and Hansel (1989). They suggested that large clasts that were held within the ice were dragged through the subglacial sediment and, because it was saturated, the till ploughed up in front of the clast. This is probably what happened at Vestari-Hagafellsjökull.

The tail of small stones behind the large clast may have formed because, once the large clast acted as an obstacle to flow, smaller clasts were stacked up on its stoss side. This is further indicated by the relatively high strength of the fabric in the tail. If this mechanism is correct, this would imply that clasts were moving at different velocities within the deforming layer. That is, the sediment within the deforming layer must have behaved as a shear zone at the base of a slow-moving debris flow as suggested by Alley and others (1987) and Clark (1991).

The second type of lineation (type b) has a longer leeside prow forming a till ridge, merging with those from other clasts, and a clast-rich tail. The sandy till ridge in Figure 6b may have been, in part, ploughed up in front of the larger clasts but this would not account for its full length. It seems more likely that a low-pressure area 
developed in front of the clast and that till was forced into this pressure shadow. They were therefore formed as mini-flutes. The clast tails associated with some of the larger clasts were probably formed in the way suggested above for type a lineations.

The third type of lineation (type c) consists of coalescing till ridges with clast-rich furrows. These till ridges may have formed both as prows (due to ploughing) and mini-flutes, with clasts again collecting in the stoss areas.

The fourth type of lineation (type d) consists of more regular lines of till ridges and clast-rich furrows. These may be a further evolution from the third type. Specifically, flute-like ridges of till occur down-glacier from larger clasts, whilst the clasts fill the areas between ridges. The clasts associated with the lineations, although oriented, are not imbricated as would be expected of a lodgement till. The fabric strength, $\mathrm{S} 1$, ranges from 0.55 to 0.825 , with an average value of 0.677 , and thus is typical of that inferred for a deforming-bed till with a thin deforming layer (Hart, 1994).

These lineations may represent a continuum of increasing deformation, from a single large clast that produces a lee-side prow and stoss-side tail (type a) through to a collection of clasts that create a series of till ridges with the lee-side flute and clast-rich stoss-side tails (type d).

The clast-rich surface could be formed in a number of ways:

(a) A residual from the removal of fines from fluvial activity. This is unlikely because of the observations of the clast-rich layer beneath the ice at Fjallsjökull and Myrdalsjökull (Krüger, 1993).

(b) Local particle-size sorting due to lodgement (Krüger, 1993). This, too, is unlikely as there is little evidence for lodgement at this site and very strong evidence for subglacial deformation. Furthermore, it is not clear how the lodgement process could sort clasts.

(c) "Depositional" deforming-bed boulder pavement. Both Hicock (1991) and Clark (1991) have suggested that boulder pavements form in deformingbed tills because heavier clasts sink to the bottom. This is not the process that occurred at the present site because the boulder pavement is at the top of the sequence. (d) "Erosional" deforming-bed boulder pavement within the deforming layer, particles of different sizes can move at different velocities. The finer particles can be moved away down-glacier, whilst the coarser particles could remain as an erosional lag (see Fig. $9)$. In this way, the deforming bed has "winnowed" away the fines.

Given the other evidence for deforming-bed conditions at this site, the latter explanation is the most likely. The lineations probably form under conditions where the deforming bed is thin due to its marginal situation (i.e. low basal shear stress) (Boulton and Hindmarsh, 1987; Hart and others, 1990). However, there is also evidence that the deforming layer consists of two layers of contrasting competence: an upper rapidly deforming layer of clasts and a lower more slowly deforming layer of sandy till. The presence of two deforming layers is very common in front of Icelandic glaciers travelling over deformable beds and was first suggested by Boulton and Dent (1974) but also observed by Dowdeswell and Sharp (1986). At this site, the upper deforming layer has produced a boulder pavement, whilst the lower, more slowly moving layer has formed the ridges and mini-flutes (Fig. 9).

\section{The different scales and superimposition of streamlined bed forms}

It was shown above that there are three scales of streamlined bed forms: drumlins, flutes and lineations, and it was argued that these are interlinked and formed by deformational processes. These are shown schematically in Figure 10. All three bed forms have the following similarities:

(a) A rigid core, which for the lineations and flutes was a clast and for the drumlins was a tumulus.

(b) A lee-side till ridge which was postulated to have formed by the movement of saturated material into the lee of the core.

However, there were also some differences in the formational processes:

(i) The core clasts associated with the lineations and flutes could and probably did move, whilst the drumlin cores were fixed. Thus, the flutes and

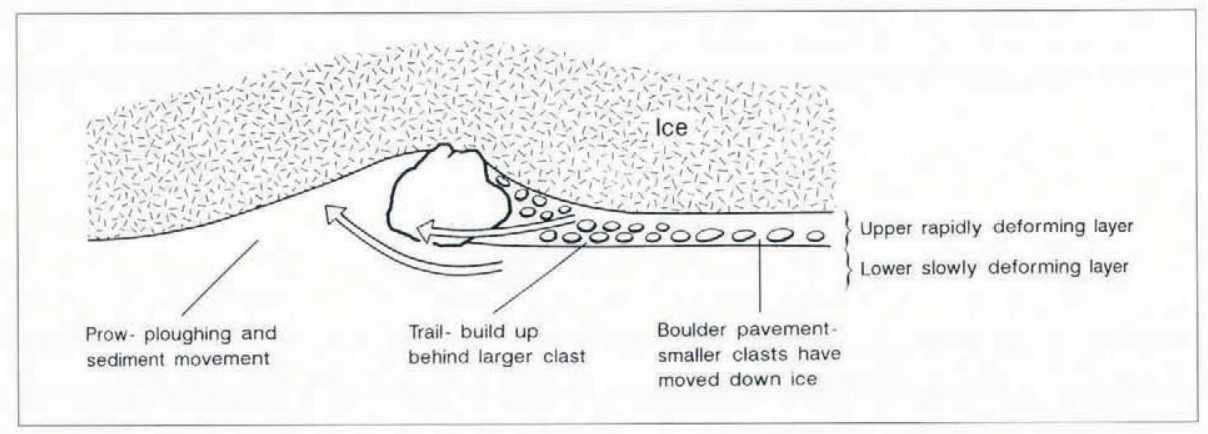

Fig. 9. The formation of lineations. The upper rapidly deforming layer produces the boulder pavement and the lower more slowly deforming layer produces the ridges and mini-flutes. 


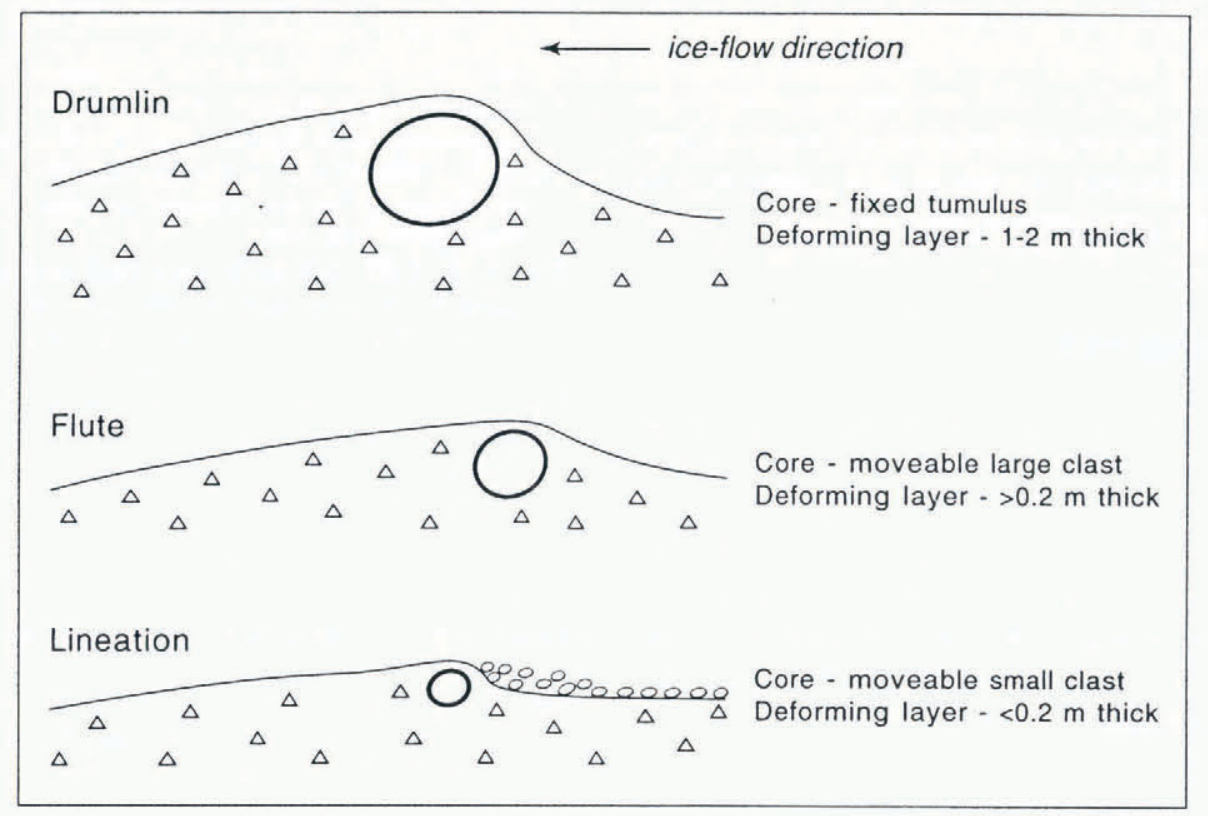

Fig. 10. Schematic diagram of the streamlined bed forms at Vestari-Hagafellsjökull.

lineations are more mobile features and this may explain why the flutes were much longer than the drumlins. However, flutes may also be longer because they are formed under thinner ice which has a slower closure rate.

(ii) The flutes and drumlins have a relatively high relief $(>0.2 \mathrm{~m})$ and are composed of sandy till with a few clasts. The lineations consist of very low clast ridges surrounded by clast-rich areas. Flutes and drumlins seem to be associated with a thick $(>0.2 \mathrm{~m})$ deforming layer, whilst the lineations may be associated with a thin deforming layer $(<0.2 \mathrm{~m})$.

(iii) Associated with the lineations there was stoss-side stacking behind the core of the bed form. Although this was not observed in the flutes and drumlins at this site, stoss-side stacking on a larger scale has been observed in drumlins (Hart, 1995). On a single-clast scale, this stoss-side stacking has also been observed in Quaternary till sequences (clast clusters) (e.g. Stea and Brown, 1989) and may not always be an indication of lodgement till as suggested by Boulton and Paul (1976) but may rather be indicative of deforming-bed conditions.

It seems plausible that the size of the bed form scales with the thickness of the deforming layer. Thus, the drumlins may have been formed when the deforming layer is approximately $0.5-2 \mathrm{~m}$ thick, the flutes when it is $0.2-0.5 \mathrm{~m}$ thick and the lineations at a thickness of $<0.2 \mathrm{~m}$.

Within this site there are many instances in which flutes and lineations are superimposed on the drumlins. It has been shown by Rose and Letzer (1977), van der Meer (1983), Krüger and Thomsen (1984) and Rose (1987, 1989) that there is often superimposition of one streamlined drift form over another. The thickness of the deforming layer has been shown to relate to the effective pressure, basal shear stress and the nature of the under- lying sediment (Boulton and Hindmarsh, 1987; Hart and others, 1990). If the streamlined bed forms at different scales are related to different thicknesses of the deforming layer, then, assuming the above parameters remain constant, as the glacier retreats so the deforming laver will thin and smaller streamlined bed forms will be superimposed on the larger ones.

\section{CONCLUSIONS}

There are three distinct scales of streamlined bed forms at Vestari-Hagafellsjökull and, although smaller ones are superimposed upon larger ones, all are postulated to have been formed by similar processes.

Flutes are the intermediate-size bed forms and these have a mobile core (clast). These are thought to have been formed by material moving into a lee-side pressureshadow area. Drumlins are the largest feature; they have a fixed core tumulus). These are interpreted to have formed in a similar way to flutes, with subglacial material collecting in the pressure-shadow areas in the lee of the core. These features were both formed of sandy till, implying one thick deforming layer.

At the smallest scale are the lineations, of which there were four types, all of which appear to have had a mobile core (clast). These form in a sandy till with an upper, oneclast thick, clast-rich layer. This is interpreted to be a boulder pavement resulting from net subglacial deforming-bed erosion. The simplest lineations were probably formed by large clasts which were held by the glacier and thus ploughed through the deforming layer type a). This produced a lee-side prow of sandy till and a stoss-side tail of clasts. In others, the frontal prow becomes elongated because material from the deforming layer moves into the pressure-shadow area, forming a mini-flute (type b). These mini-flutes sometimes formed till ridges, some of which coalesced (type c), whilst others remained parallel (type d).

It seems probable that the bed forms were formed 
during subglacial deformation but in association with different thicknesses of the deforming layer. As the thickness of the deforming layer changed, perhaps as the glacier retreated, one style of subglacial bed form was superimposed upon another. In this way a continuum of subglacial bed forms was formed.

\section{ACKNOWLEDGEMENTS}

I should like to thank K. Martinez for his help in the field, J. Rose for drawing my attention to the site and the Icelandic Research Council for permit 92037. I should also like to thank A. Burns and his colleagues in the Cartographic Unit for figure reproduction and Dr R. LeB. Hooke and M. Hendy for useful comments on the text. This field work was funded by a University of Southampton small grant.

\section{REFERENCES}

Alley, R. B., D. D. Blankenship, C. R. Bentley and S. T. Rooney. 1986. Deformation of till beneath Ice Stream B, West Antarctica. Vature. $3226074), 57-59$.

Alley, R. B., D. D. Blankenship, C. R. Bentley and S. T. Rooney. 1987. Till beneath Ice Stream B. 3. Till deformation: evidence and implications. 7. Geophys. Res., 92 B9), 8921-8929.

Amark, M. 1980. Glacial flutes at Isfallsglaciären, Tarfala, Swedish Lapland. Geol. Fören. Stockholm Förh., 102 (3), 251-259.

Benn. D. 1. 1994. Fluted moraine formation and till genesis below a temperate valley glacier: Slettmarkbreen, Jotunheimen, southern Norway. Sedimentology, 41 2), 279292.

Boulton, G.S. 1975. Processes and patterns of subglacial sedimentation: a theoretical approach. In Wright, A. E. and F. Moseley, eds. Ice ages: ancient and modern. Liverpool, Seel House Press, 7-42.

Boulton, G.S. 1976. The origin of glacially fluted surfaces observations and theory. \%. Glaciol., 17 (76), 287-309.

Boulton, G. S. 1979. Processes of glacier erosion on different substrata. J. Glaciol., 23 89), 15-38.

Boulton, G.S. 1986. Push moraines and glacier-contact fans in marine and terrestrial environments. Sedimentology, 33 5), 677-698.

Boulton, G.S. 1987. A theory of drumlin formation by subglacial sediment deformation. In Menzies, J. and J. Rose, eds. Drumlin Symposium. Rotterdam, A. A. Balkema, 25 80.

Boulton, G.S. and D. L. Dent. 1974. The nature and rates of postdepositional changes in recently deposited till from south-east Iceland. Geogr. Ann., 56A (3-4), $121-134$.

Boulton, G.S. and R. C.A. Hindmarsh. 1987. Sediment deformation beneath glaciers: rheology and geological consequences. J. Geophys. Res., 92 B9), 9059-9082.

Boulton, G.S. and M. A. Paul. 1976. The influence of genetic processes on some geotechnical properties of glacial tills. Q. J. Eng. Geol., 9, $159-194$.

Brown, N. E., B. Hallet and D. B. Booth. 1987. Rapid soft bed sliding of the Puget glacial lobe. 7. Geophys. Res., 92 B9), 89858997.

Cas, R.A.F. and J. V. Wright. 1986. Volcanic successions: ancient and modern. London, etc., Allen and Unwin.

Clark, P.U. 1991. Striated clast pavements: products of deforming subglacial sediment? Geolog), 19(5), 530-533.

Clark, P. U. and A. K. Hansel. 1989. Clast ploughing, lodgement and glacier sliding over a soft glacier bed. Boreas, 18 3), 201-207.

Dowdeswell, J. A. and M.J. Sharp. 1986. Characterization of pebble fabrics in modern terrestrial glacigenic sediments. Sedimentolog), 33 (5), $699-710$.

Dreimanis, A. 1993. Water-eroded crescentic scours and furrows associated with subglacial llutes at Breidamerkurjökull, Iceland. Boreas, 22(2), 110-112.
Dyson, J. L. 1952. Ice-ridged moraines and their relation to glaciers. Am. 7. Sci., 250 3), 204211.

Gordon, J. E., W. B. Whalley, A. F. Gellatly and D. M. Vere. 1992. The formation of glacial flutes: assessment of models with evidence from Lyngsdalen, north Norway. Quat. Sci. Rev., 11(7-8), 709-731.

Hart, J. K. 1990. Proglacial glaciotectonic deformation and the origin of the Cromer Ridge push moraine complex, north Norfolk, England. Boreas, 19 2), 165-180.

Hart, J.K. 1994. Till fabric associated with deformable beds. Earth Surface Processes and Landforms, 19 1), 15-32.

Hart, J. K. 1995. Drumlin formation in southern Angelsey and Arvon, north-west Wales. J. Quat. Sci., 10, 3-14.

Hart, J. K. and G.S. Boulton. 1991. The interrelation of glaciotectonic and glaciodepositional processes within the glacial environment. Qual. Sci. Rev., 10 (4), 335-350.

Hart, J.K., R.C.A. Hindmarsh and G.S. Boulton. 1990. Styles of subglacial glaciotectonic deformation within the context of the Anglian ice-sheet. Earth Surface Processes and Landforms, 15 3), 227 241.

Hicock, S. R. 1991. On subglacial stone pavements in till. J. Geol., 99(4), $607-619$.

Hicock, S. R. and A. Dreimanis. 1992. Deformation till in the Great Lakes region: implications for rapid flow along the south-central margin of the Laurentide ice sheet. Can. J. Earth Sci., 29 7), 1565 1579 .

Krüger, J. 1993. Moraine-ridge formation along a stationary ice front in Iceland. Boreas, 22 2), 101-109.

Krüger, J. and O. Humlum. 1981. The proglacial area of Mýrdalsjökull with particular reference to Sléttjökull and Höfdabrekkujökull. Folia Geogr. Dan., 15, 1-58.

Krüger, J. and H. H. Thomsen. 1984. Morphology, stratigraphy, and genesis of small drumlins in front of the glacier Mýrdalsjökull, south Iceland. J. Glaciol., 30 (104), 94105.

Mark, D.M. 1973. Analysis of axial orientation data, including till fabrics. Geol. Soc. Am. Bull., 84(4), 1369-1374.

Meer, J.J. M. van der. 1983. A recent drumlin with fluted surface in the Swiss Alps. In Evenson, E. B., C. Schlüchter and J. Rabassa, eds. Tills and related deposils: genesis/petrology/application/stratigraphy. Rotterdam, A. A. Balkema, 105-109.

Menzies, J. 1979. The mechanics of drumlin formation with particular reference to the change in pore-water content of the till. f. Glaciol., $2287), 373-384$.

Menzies, J. 1984. Drumlins: a bibliograply. Norwich, Geo Books.

Paul, M. A. and H. Evans. 1974. Observations on the internal structure and origin of some flutes in glacio-fluvial sediments, Blomstrandbreen, north-west Spitsbergen. J. Glaciol., 13 69), 393400.

Price, R.J. 1970. Moraines at Fjallsjökull, Iceland. Arct. Alp. Res., 2(1), $27-42$.

Rose, J. 1987. Drumlins as part of a glacier bedform continuum. In Menzies, J. and J. Rose, eds. Drumlin Symposium. Rotterdam, A. A. Balkema, 103-116.

Rose, J. 1989. Glacier stress patterns and sediment transfer associated with the formation of superimposed flutes. Sediment. Geol., 62 $2 / 4)$, $151-176$.

Rose, J. and J. M. Letzer. 1977. Superimposed drumlins. J. Glaciol., $1880), 471-480$.

Sharp, M. 1984. Annual moraine ridges at Skálafellsjökull, south-east Iceland. J. Glaciol., 30 (104), 8293.

Shaw, J. 1983. Drumlin formation related to inverted melt-water erosional marks. J. Glaciol., 29 103), 461-479.

Sigurdsson, O. 1988. Jöklabreytingar 1930-1960, 1960-1980, 1980-1986 og 1986-1987. Jökull, 38, 91-97.

Smalley, I.J. and D.J. Unwin. 1968. The formation and shape of drumlins and their distribution and orientation in drumlin fields. $\mathcal{f}$. Glaciol., 7 51 ), 377-390.

Stea, R. R. and Y. Brown. 1989. Variation in drumlin orientation, form and stratigraphy relating to successive ice flows in southern and central Nova Scotia. Sediment. Geol., 62 (2/4), 223-240.

Theódórsson, T. 1980. Hagafellsjöklar taka á rás. Jökull, 30, 75-77.

Thórarinsson, S. 1943. Vatnajökull; scientific results of the SwedishIcelandic investigations 1936-37-38. Oscillations of the Iceland glaciers in the last 250 years. Geogr. Ann., $25(1-2), 1-54$. 